\title{
ENVIRONMENTAL CRIMES LISTED IN THE Polish Penal Code Since 1997
}

\author{
Małgorzata Szwejkowska, Elżbieta Zębek ${ }^{1}$
}

\author{
Faculty of Law and Administration, University \\ of Warmia and Mazury, Poland \\ email: redakcja.wpia@gmail.com
}

\begin{abstract}
SZWEJKOWSKA, M. - ZĘBEK, E. Environmental crimes listed in the Polish Penal Code since 1997. International and Comparative Law Review, 2013, Vol. 13., No. 2, pp. 111-119. DOI: 10.1515/iclr-2016-0074.
\end{abstract}

\begin{abstract}
Legal requirements for protection of the natural environment are continually being strengthened because of increased human damage to environmental resources. The applicable regulations of the Polish Penal Code towards protection of the environment were considerably amended in 2011 also to ensure implementation of European Parliament and European Council directives 2008 / 99 / EC, issued on the 19th November 2008. In addition, these changes also involve cross-border infringements, so that perpetrators cannot avoid retribution for actions committed under different provisions in individual Member States.
\end{abstract}

Keywords: environmental protection, environmental damage, crimes against nature, Polish Penal Code, EC directives

\section{Introduction}

Legal requirements for protection of the natural environment are continually being strengthened because of increased human damage to environmental resources. The Polish environment currently has protection from the following; (1) civil law compensation for environmental damage through administrative and legal procedures. These limit damage by regulating compensation and imposing sanctions for administrative torts, and (2) the National Polish legaldisciplinary administation which is has powers in prevention and compensation for the environmental harm caused. Here, environmental protection under the Polish penal law system provides address for both petty offences and serious criminal offences. Petty offences come under the Code of Petty Offences and crimes against the environment are most often classified under chapter XXII of the Penal Code ${ }^{2}$, or by regulations of alternative acts recognized as uncoded criminal law.

1 Faculty of Law and Administration, University of Warmia and Mazury, Poland.

2 However, forbidden acts against the environment can also be penalized based on provisions beyond this chapter. These include; i illegal forest tree-felling, covered by article 290 $\$ 1$ of the Penal Code, and killing unprotected animal species outside protected areas, in 
The provisions of the petty offences law in Poland are so far-reaching that its treatment here surpasses the scope of this article. Consequently, this article analyses the codified regulations for crimes committed in the field of environmental protection. However, penal measures in this area mainly have a subsidiary ${ }^{3}$ function, and they are largely enforced when civil law and administrative-legal procedures cannot ensure adequate environmental protection against unauthorized human action and damage.

Before the Penal Code of 1997 came into force, the scope of legal-criminal environmental protection was insufficient. Penalties were imposed for behaviour such as; (1) hunting and fish poaching under the 1932 Penal Code, and (2) Article 122 of the Water Law Act of 24th October 1974 covered water pollution crimes considered dangerous for life, human health and plant and animal welfare. The most significant legislative introduction was the provision under article $140 \S 1$ point 2 of the 1969 Penal Code for crimes "universally dangerous and harmful by water, air or earth pollution". This Code covered both intentional and inadvertent perpetrator behaviour. The unabridged code of regulations passed by the Republic of Poland Parliament on the 6th June 1997 brought the first important interventions against environmental crimes; as discussed in the following chapter.

The applicable regulations in chapter XXII of the Polish Penal Code were considerably amended in 2011 to ensure implementation of European Parliament and European Council directives 2008 / 99 / EC, issued on the 19th November 2008. These required enforcement of criminal liability for environmental damage. Therefore, the number of liable acts against the environment, appropriately coded with the crime's designation and description, have increased in the polish Penal Code since the 10th June 2011. Possibilities for prosecuting criminal liability of people responsible for managing environmental undertakings were also widened. This is codified as functions causing environmental damage, or posing a threat of such damage.

The following Acts are applied under the Polish Penal Code to combat environmental crimes; (1) the 16th April 2004 Act for nature conservation; (2) the 29th November 2000 Atomic Law Act; (3) the 29th September 1991 Act for forest protection; (4) the 13th October 1995 Hunting law; (5) the April 2001 environment protection Act, (6) the 18th July 2001 Act for inland waters conservation and (7) the 14th December 2012 Act covering the handling of waste.

Criminal offences against the environment in chapter XXII of the Penal Code were unified in eight articles, dividing crimes into two types of punitive offences;(1) protection against pollutants and acts injurious to humans and the

article $288 \$ 1$ of the Penal Code.

3 A. Marek, Criminal law, Warszawa 2003, p.461. 
natural environment and (2) procedures ensuring legal-criminal conservation of nature. ${ }^{4}$

\section{Actions injurious to animals and plants.}

Article 181 \$1 of the Penal Code defines the liable "significant extent" of damage caused to plants and animals subjecting proven perpetrators to imprisonment from 3 months to 5 years, with fines for unintentional damage. The following Article 181 provides fines or restriction of freedom or up to 2 years imprisonment for the following:( 1) unintentional damage, under Article subsection $181 \$ 4,(2)$ destruction or significant damage to plants and animals in protected areas, under $181 \$ 2$ (3) unintentional responsibility for provision (2) above under181 $\$ 5,(4)$ destruction or significant damaged to protected plant and animal species irrespective of where this occurs, under. $181 \$ 3$, and (5) unintentional responsibility for provision (3), under $181 \S 5$.

These provisions ensure that plants and animals are protected: (A) in entirety; that is, not only individual plants and animals species in the wild, but also those on farms and horticulture, under sub-section Articles $181 \$ 1$ and $\$ 4$ of the Penal Code; (B) those in all areas covered for nature protection under Articles $181 \S 2$ and $\$ 5$, and (C) those protected species under regulations laid down by the Minister for Environmental Protection, Natural Resources \& Forestry ${ }^{5}$

Although a lot of damage caused to plants and animals is irremediable, ${ }^{6}$, further damage can be limited by strict legislation and its enforcement. Beyond the scope of this norm remains the case when the perpetrator caused the only the damages possible to turn away among plants or animals". "However, damage by an offender which is remediable and reversible is not covered in this legislation. Currently increased sanctions for plant and animal damage differ depending on whether the damage was caused deliberately or unintentionally. However, in both cases, the major factor to be considered is the actual extent of the damage. Examples of major damage are (1) irreversible losses of large plant areas by cutting hectares of forest, and (2) extensive damage to a large number of animals resulting, for example, from heavily polluted waters eliminating fish species from a lake. Current jurisdiction is decided on the spatial scope of plant and animal damage, rather than on resultant financial losses. ${ }^{8}$ To this end, criminal

4 W. Radecki, Crimes against the environment in: Penal Code. Commentary, vol.I, A. Wąsek (ed.), Warszawa 2004, p. 591.

5 That is the regulations of the Minister for Environmental Protection, Natural Resources \& Forestry : from 12th October 2011 about the species protection of animals and from 5th January 2012 about the species protection of the plants,

6 W. Radecki, Crimes against the environment in: Penal Code. Commentary, M.Filar (ed.), Warszawa 2010, p. 863.

7 M. Szwejkowska, W. Truszkowski, Destroying natural resources in art. 181 of the Penal Code, Przegląd Policyjny no 2/2012, p. 192.

8 Compare the Verdict of the Supreme Court e.g. From the 27th July 1984,, IV KR 176 / 84, 
law interprets signicant destruction of plant and animal resources as damage (1) to at least 1 hectare of land and inland water basins, (2) at least 2 hectare of salt water, and (3) at least 5 square kilometres of flowing waters ${ }^{9}$. Although this legal application appears justified in flora destruction, for fauna losses it would be more appropriate to assess the number of affected animals rather than the size of the area involved.

In addition, assessment of penalties for significant destruction or damage to animals in legally protected areas such as national parks and Nature 2000 declared areas should be judged on ecological criteria. However, current penalties for such actions are mainly independent of where the offence took place; whether it be a protected area or agricultural or urban settings.

\section{Polluting the natural environment}

Article 182 of the Penal Code covers environmental pollution. It legislates for water pollution and also air and soil pollution, by all substances including ionising radiation in such amounts and in such forms that threaten human life or health. Significant intentional damage to water, air and soil quality and significant plant or animal destruction makes the perpetrator liable to imprisonment from 3 months to 5 years under Article $182 \S 1$. Where such actions are unintentional, the person is liable to a fine, restriction of freedom or imprisonment up to 2 years under Article $182 \$ 2$. The severity of the penalty increases when environmental pollution is caused by installations established under licence. Here, the intentional offender faces imprisonment ranging from 6 months to 8 years under Article $182 \S 3$, and unintentional damage incurs the penalty of imprisonment up to 3 years under Article $182 \$ 4$.

In this entire field of human, fauna and flora protection, enviromental pollution is the criminal offence most frequently prosecuted .Sanctions against pollution of water, air and soil is mainly directed at harmful substances and ionizing radiation, but other environmental energy offences have been omitted from the Penal Code. Together with ionising radiation, these additional actions cause the greatest threats to human life and health. Prior to amendments, the Penal Code legislated against recognized threats to human health and life, and significant damage to animals and plants. The legal evaluation of energy-supply pollution was based on emission standards which preserved environmental quality, but criminal sanctions could not be imposed unless these legislated standards were violated ${ }^{10}$. The Penal Code currently has no provision for pollution caused by

OSNPG 1985, pos. 34

9 W. Radecki, Crimes against the environment in: Penal Code. Commentary, M.Filar (ed.), Warszawa 2010., p. 865.

10 R. Dziembowski, M. Szwejkowska, E. Zębek „Legal-criminal resource protection of the environment "in:" Illegal exploitation of forest resources", W. Pływaczewski, M. Duda (ed), Olsztyn 2013, p.147. 
licensed plants and installations. ${ }^{11}$. Article 3 point 6 in the 27th April 2001 Act for Environment Protection defines an installation as a "stationary technical device, a group of stationary devices united technologically, to which one entity has legal title, and this is established on the area of one plant, together with buildings which are not technical devices in themselves, but their utilization can cause emission." Further, Article 3 point 48 of the Environment Protection law defines the word "plant" here as 'one or a few installations together with the area to which the person has a legal title and all devices on it.

The most severe penalties under Article 182 are covered in Article 185 of the Penal Code which legislates up to 12 years imprisonment for widespread.human health hazard and death, serious destruction of plant and animal life, and harmful effects on water, air and soil quality.

\section{Illegal waste and radioactive material disposal}

Article 183 of the Penal Code provides protection against environmental risks associated with illegal waste disposal. It imposes fines or up to 2 years imprisonment depending on the seriousness of deliberate or unintentional unauthorized waste disposal. To this end, Article $183 \$ 6$. enacted on 14th December 2012, defines offences committed in performance of the following;(1) the storage, removal, processing, recycling, neutralizing and transport of waste materials in conditions or quantity that threaten human health or life (2) significant harm to water, air or soil quality, and (3) possible or actual serious impairment to plant and animal welfare. Penalties imposed for violations in these classes are enforced under Article $183 \$ 1$.of the Penal Code, to the extent of imprisonment from 3 months to 5 years. In addition, Article $183 \$ 2$ prohibits illegal import of substances threatening the environment; with possible imposition of 3 months to 5 years imprisonment. This same penalty is enforceable under Article. $183 \$ 3$ for persons in duty-obliged positions who allow aid or abet perpetrators to illegally import or export waste. Where the imported or exported waste is categorised as dangerous, guilty perpetrators and enablers are liable to 6 months to 8 years imprisonment under Article $183 \$ 4$.

Article 183 of the Penal Code penalizes unlawful management and import and export of all waste and listed substances under the following headings

1. storage - location of waste in places appointed as long-term landfill sites and other civil structures ${ }^{12}$;

2. removal - transporting waste and substances from its origins ${ }^{13}$;

11 S. Raniszewski, The directive of the European Parliament and European Council on the environmental protection through the criminal law and for its implementation into the Polish law, Przegląd Prawa Ochrony Środowiska no 2/2012, p. 82.

12 Art. 3 point 25 of the Acts from the 14th December 2012 about waste.

13 Lack of legal definition. 
3. processing - recycling and neutralizing processes; including waste-preparation preceded by recycling or neutralization ${ }^{14}$;

4. recycling - involves all processes where waste serves useful application in replacing other materials, and "which otherwise would be used in fulfilling the given function, or results in waste prepared for fulfilling such a function, at the given site and for economic benefit"15;

5. neutralization - includes all processes not aimed at recycling. This covers subjecting waste and listed substances to biological, physical or chemical transformation to render them suitable for ensuring human health, and posing no environmental threat. ${ }^{16}$

6. transport - covers all waste and listed-substance transfers involved in import and export ${ }^{17}$.

Criminal behaviour under Article 183 of the Penal Code covers all waste and listed substances Included therein is all dangerous waste construed as such in the Minister for Environmental Protection, Natural Resources \& Forestry catalogue regulations. This includes all substances posing a threat to human health and life by their biological, radioactive or chemical properties. This is laid down in Article 3 point 37 of the 27th April 2001 Acts for environmental protection

Article 184 of the Penal Code legislates against unlawful dealing with radioactive materials It penalizes the following; production, process activities, possession, accumulation, storage and import and export of nuclear material or alternative sources of ionizing radiation.. It also covers human life-threatening use, removal, discard or abandonment of any nuclear material or ionising radiation without appropriate protection, or causing significant decrease in water, air and soil quality, or endangering plant or animal wefare. Article184 $\$ 1$ legislates liabilty to imprisonment from 3 months to 5 years for intentinal acts, and Art. $184 \$ 3$ sets the penalty at up to 2 years imprisonment for unintentional breaches. In addition, persons or groups enabling the commission of these violations are subjected to imprisonment from 3 months to 5 years-under Article $184 \$ 2$ for intentional acts, and the enforceable penalty for unintentional breaches of this code under Article. $184 \$ 3$ is up to 2 years imprisonment. The catalogue of causative behaviours is much wider than for those defined in Article 183 of the Penal Code. As well as including all the abovementioned unlawful dealings with harmful materials, it's definitions of these dealings is more stringent. Here, it stresses that; (1) development and production of radioactive materials include every activity initiating the exisistence of that material; (2) accumulation and storage include temporary storage (3) possession involves all actions empowering radio-

14 Art. 3 point 21 of the Acts from the 14th December 2012 about waste.

15 Art. 3 point 14 of the Acts from the $14^{\text {th }}$ December 2012 about waste.

16 Art. 3 point 30 of the Acts from th 14th December 2012 about waste.

17 Lack of legal definition. 
active material, and (4); discard and abandonment include all insufficien protection against these substances.

Articles 183 and 184 of the Penal Code subject perpetrators to the most severe criminal sanction when their actions cause: (1) human death, (2) extreme widespread damage to human health (3) animal and plant destruction to a significant degree and (4) significant decrease in water, air and soil quality. The criminal sanction is increased here, so that Article 185 of the Penal Code currently legislates up to 12 years imprisonment for these serious crime.

\section{Other crimes against the environment}

Article 186 of the Penal Code sanctions failure to apply and maintain appropriate order for devices preserving water, air and soil quality. This also applies to all devices required for appropriate radioactive and ionizing radiation safety. Here, intentional perpetrators are liable to a fine, restriction of freedom or imprisonment up to 2 years under Article. $186 \$ 1$, and unintentional acts carry liability of a fine or restriction of freedom under Article186 $\$ 3$. In addition, persons who neglect their duty of "forbidding the use of a civil structure or a group of objects lacking the protection devices required by law" are subjected to a fine, restriction of freedom or imprisonment up to 2 years under $186 \$ 2$; and unintentional acts in this regard are subject to a fine or restriction of freedom under Article $186 \$ 3$.

Article 186 of the Penal Code legislates against failure in preservation or application of protection devices in the defined adequate state of repair. These include devices preserving water, air and soil quality from pollutants, and safety devices preventing radioactive or ionizing radiation emission. Responsibility for this criminal activity is limited to entities who have the legal obligation to maintain these facilities in proper repair.

Article 187 oversees significant decay, damage or reduction in the natural value of legally protected areas and objects These include natural monuments, national parks, reserves, Nature 2000 areas, enviromental use areas and other forms of nature conservation. Liable activities here include, for example, cutting down protected trees and building roads in protected areas where mechanical vehicles destroy surrounding areas. The penalties here depend on the degree of damage inflicted. Deliberate actions under this Article are punishable by a fine, restriction of freedom or imprisonment up to 2 years under $187 \$ 1$, and unintentional commission also incurs a fine or restriction of freedom under $187 \$ 2$.

The last regulations for enviromental protection under the Penal Code covers land use violation by unlawfully building or expanding objects, and business activities harmful to protected area environments. Here, guilty perpetrators are liable to a fine, restriction of freedom or imprisonment up to 2 years under Article 188 of the Penal Code 


\section{Conclusions}

Polish ecological politics are currently based on permanent tasks and aims which comply with European Union directives. Therefore, these directives for environmental protection imposed by the European Parliament and European Council are subject to the Polish Penal Code because this has the strictest enforceable sanctions; including imprisonment. Current sanctions in many Member States based solely on civil and administrative sanctions do not provide sufficient deterrents for adequate protection; including protection of the environment itself, human health, safe water, air and soil, and ensuring plant and animal welfare.

Changes in Polish compliance with European Union directives also encompass non-criminal law. Here, the Conservation Act of the 16th April 2004 provides penalties for violating provisions enacted for plant and animal protection. For example, this Act sets a limit set on the number of specimens of animals, plants and protected mushrooms species persons or entities are able to keep, with intentional infringements of these limits incurring 3 months to 5 years imprisonment under Article 127 of the Act .However, sanctions here are dependent on proof that the offender's actions violated the protected species's welfare, and unintentional contraventions subject the offender to, restriction of freedom or imprisonment for up to 2 years. The Conservation Act also legislates for legal and appropriate import, transport and turnover of protected species specimens, with contraventions incurring a penalty of three months to 5 years imprisonment under Article 128.

The extended scope of criminal liability for environmental damage and concurrent increased sanctions will contribute to more effective environmental protection in Poland. In addition, it has been emphasized that these changes also involve cross-border infringements, so that perpetrators cannot avoid retribution for actions committed under different provisions in individual Member States ${ }^{18}$.

Recorded Polish police statistics highlight that criminal proceedings have been increasingly initiated in recent years for crimes contravening Chapter XXII of the Penal Code. Their statistics reveal that these proceedings have risen from 5,883 in 2008 to 6,127 in 2009. The Table below gives an indication of the number of crimes seriously contravening individual Articles prosecuted in 2011.

18 E. Wiszniewska, „The restriction of the criminal law for crimes against the natural environment, available on: http://www.eko-samorzadowiec.pl/pl/ekologia/artykuly_i_porady/429. html [access: 6.11.2011], 
ICLR, 2013, Vol. 13, No. 2.

Crimes against the enviroment (2011)

\begin{tabular}{|l|c|}
\hline Legal characterisation & $\begin{array}{c}\text { Number } \\
\text { of crimes }\end{array}$ \\
\hline Art. $181 \S 1-5$ of the Penal Code - destroying the natural legacy & 72 \\
\hline $\begin{array}{l}\text { Art. } 182 \S 1-4 \text { of the Penal Code - polluting or contaminating the envi- } \\
\text { ronment }\end{array}$ & 60 \\
\hline $\begin{array}{l}\text { Art. } 183 \S 1-4 \text { of the Penal Code inappropriate dealing with substances } \\
\text { that threaten people and the environment }\end{array}$ & 99 \\
\hline $\begin{array}{l}\text { Art. } 184 \S 1-3 \text { of the Penal Code - inappropriate dealing with radioactive } \\
\text { materials }\end{array}$ & 0 \\
\hline $\begin{array}{l}\text { Art. } 185 \S 1-2 \text { of the Penal Code - destruction of flora or fauna in sig- } \\
\text { nificant degree or numbers, causing human death or widespread damage } \\
\text { to human health incurred under Art. } 182 \S 1,183 \S 1 \text { lub 3, 184 } \$ 1 \text { or } 2)\end{array}$ & 1 \\
\hline $\begin{array}{l}\text { Art. } 186 \S .1-3 \text { of the Penal Code - neglecting required actions for envi- } \\
\text { ronmental protection }\end{array}$ & 7 \\
\hline $\begin{array}{l}\text { Art. } 187 \S 1-2 \text { of the Penal Code - occurrence of significant damage to } \\
\text { protected areas or objects }\end{array}$ & 17 \\
\hline Art. 188 of the Penal Code- violating the protection of conserved nature & 9 \\
\hline
\end{tabular}

